\title{
IZABELA JUHNKE
}

Akademia Ekonomiczno-Humanistyczna w Warszawie

izabelajuhnke@interia.pl

\section{IDEA POSTĘPOWANIA \\ ZABEZPIECZAJĄCEGO - STUDIUM PRZYPADKU}

\section{THE IDEA OF THE PRECAUTIONARY PROCEDURE - A CASE STUDY}

\begin{abstract}
STRESZCZENIE
Niniejszy artykuł jest analizą regulacji prawnych dotyczących prowadzenia postępowania zabezpieczającego w sprawach opiekuńczych. Podjęto w nim próbę wykazania, iż postępowanie zabezpieczające ma na celu zabezpieczenie interesów strony wnioskującej oraz staje się instrumentem osiągania celów w danym postępowaniu. Niniejsze opracowanie obrazuje problematykę zabezpieczenia miejsca zamieszkania małoletniego, jak i zabezpieczenia kontaktów w postępowaniu opiekuńczym, a nadto wykorzystanie możliwości technologicznych do utrzymania więzi rodzinnych.
\end{abstract}

\begin{abstract}
This article is an analysis the legal regulations concerning conducting security proceedings in guardianship matters. An attempt has been made to prove that the purpose of the interim proceedings is to secure the interests of the applicant party and it becomes an instrument of achieving goals in a given proceeding. This study illustrates the issues of securing the minor's place of residence, as well as securing contacts in guardianship proceedings, and also taking advantage of technological opportunities to maintain family ties.
\end{abstract}


SŁowA kluczowe: uzależniony od sieci, społeczeństwo cyfrowe, władza rodzicielska, procedura zabezpieczająca, procedura, dobro dziecka

KEYWORDS: network addict, digital society, parental authority, securing procedure, procedure, child's welfare

\section{WPROWADZENIE}

Instytucja postępowania zabezpieczającego kojarzona jest $\mathrm{z}$ udzieleniem tzw. tymczasowej ochrony prawnej w toku postępowania cywilnego. Natomiast uzyskanie tej ochrony wynika $\mathrm{z}$ faktu, że z przeprowadzeniem postępowania cywilnego łączy się upływ czasu, który jest niezbędny do należytego wyjaśnienia i rozstrzygnięcia sprawy ${ }^{1}$. Należy jednak wskazać, że samo zabezpieczenie nie może zastąpić postępowania, a więc poprzez jego udzielnie nie może dojść do zaspokojenia roszczenia, gdyż wynika to z istoty zabezpieczenia, którą jest właśnie jego tymczasowość ${ }^{2}$. Można natomiast stwierdzić, że celem postępowania zabezpieczającego jest osiągnięcie pewnego stanu rzeczy, który jeszcze nie istnieje, ale do którego wnioskująca strona dąży poprzez podejmowanie określonych działań procesowych. Zabezpieczeniu podlegają roszczenia pieniężne, będące przedmiotem spraw o alimenty, jak również roszczenia niepieniężne, które natomiast są związane $\mathrm{z}$ władzą rodzicielską oraz uregulowaniem kontaktów z małoletnimi dziećmi ${ }^{3}$. Zgodnie z art. 730 Kodeksu postępowania cywilnego, dalej: k.p.c. $\left.{ }^{4}\right)$ z żądaniem udzielenia zabezpieczenia może wystąpić strona do tego uprawniona w każdej sprawie, która może być rozpatrywana na drodze sądowej, a więc w każdej sprawie cywilnej, która podlega rozpoznaniu przez sąd lub sąd polubowny. Stosowny wniosek o udzielenie zabezpieczenia może być złożony zarówno przed wszczęciem postępowania rozpoznawczego, jak i w jego trakcie. Natomiast rozpoznanie tego wniosku może nastąpić na rozprawie, ale także, w określonych przypadkach, na posiedzeniu niejawnym.

1 T. Ereciński (red.), System prawa procesowego cywilnego. Postępowanie zabezpieczające, Wydawnictwo Wolters Kluwer, Warszawa 2016, s. 27.

2 G. Jędrejek (red.), Postępowanie cywilne po nowelizacji. Vademecum, WKP 2020, http://sip. lex.pl/ (dostęp: 24.05.2021).

3 M. Strzelecka, Postępowanie w sprawach rozwodowych, „Monitor Prawniczy” 2019, nr 24, s. 1352.

4 Ustawa z dnia 17 listopada 1964 r. - Kodeks postępowania cywilnego (tekst jedn. Dz.U. z 2020 poz. 1575). 
Jak już wcześniej zaznaczono, udzielenia zabezpieczenia może żądać każda ze stron postępowania. Jednak warunkiem wystąpienia z wnioskiem o zabezpieczenie jest uprawdopodobnienie samego interesu roszczenia, ale także interesu prawnego w udzieleniu tegoż zabezpieczenia. Co to oznacza? Otóż interes prawny w udzieleniu zabezpieczenia istnieje w sytuacji, gdy jego brak poważnie utrudni lub wręcz uniemożliwi wykonanie mającego zapaść w sprawie orzeczenia bądź też osiągnięcie celu postępowania. Sąd rozpoznający wniosek o zabezpieczenie może uznać twierdzenia wnioskodawcy za uprawdopodobnione wówczas, gdy nabierze przekonania, iż prawdopodobnie tak właśnie jest, wystarczy, że zdaniem sądu prima facie roszczenie to ma szansę na powodzenie ${ }^{5}$. Wyjątkami od konieczności uprawdopodobnienia istnienia interesu prawnego są roszczenia pieniężne określone w art. $753 \$ 1$, art. 753 $\$ 3$ oraz art. 754 k.p.c.

Celem niniejszego artykułu jest analiza prowadzenia postępowania zabezpieczającego w sprawach opiekuńczych na podstawie obecnie obowiązujących regulacji prawnych zawartych w Kodeksie postępowania cywilnego rozpatrywanych na przykładzie poniższego stanu faktycznego.

\section{ZARYS STANU FAKTYCZNEGO}

Wnioskodawca wystąpił do sądu rejonowego z wnioskiem, w którym zawarte zostały trzy żądania. Po pierwsze domagał się, aby miejscem zamieszkania dziecka było każdorazowe miejsce zamieszkania ojca. Po drugie zaś wnosił o ustalenie kontaktów małoletniego syna z matką, z którą nie pozostawał już w związku. Trzecim żądaniem było udzielenie zabezpieczenia w zakresie miejsca zamieszkania małoletniego.

Warto wskazać, iż już w trakcie ciąży partnerzy stwierdzili, że nie pasują do siebie, ponieważ mają różne priorytety. Nadto ojciec odkrył, że matka przed ciążą chorowała na bulimię. Jednak mimo wszystko postanowili trwać w związku ze względu na syna, który urodził się z problemami zdrowotnymi i wymagał szczególnej opieki. Matka po porodzie popadła w depresję, co skutkowało brakiem zainteresowania dzieckiem, natomiast wzmagała się w niej

${ }^{5}$ G. Jędrejek (red.), Postępowanie..., dz. cyt. 
chęć zostania celebrytką. Twierdziła, że do życia potrzebuje ludzi i obecności w mediach społecznościowych, gdzie kreowała wyimaginowany świat idealnej matki. Miewała ataki paniki i histerii, przez co trafiła do szpitala psychiatrycznego, gdzie stwierdzono poporodowe zaburzenia psychiczne. Wszystko to spowodowało, że ojciec przejął faktyczną opiekę nad dzieckiem. Matka każdą chwilę spędzoną z synem wykorzystywała na pozowanie do wspólnych zdjęć i filmów, które miały na celu promowanie jej w mediach społecznościowych jako fitness mamy. W wyniku licznych awantur wszczęta została procedura założenia Niebieskiej Karty. Dodatkowo podczas choroby małoletniego matka postanowiła wyjechać, aby poddać się kolejnej operacji powiększenia piersi i korekty nosa, w wyniku czego nie było jej w domu przez tydzień. Po powrocie matki rodzice zdecydowali się podpisać Rodzicielski Plan Wychowawczy, ustalając nad małoletnim opiekę naprzemienną. Po pewnym czasie ojciec zauważył, że matka coraz częściej spożywa alkohol w obecności syna. Chciał, aby poddała się terapii odwykowej, do której się zobowiązała, jednak bez rezultatu. Finalnie matka została zatrzymana przez policję podczas jazdy pod wpływem alkoholu, gdy w samochodzie przewoziła syna. Sytuacja ta była punktem zapalnym do złożenia przez ojca wniosku do sądu.

W tym stanie rzeczy należy rozważyć, czy postanowienie zabezpieczające powinno być rozpoznane jako niecierpiące zwłoki oraz przy którym z rodziców powinno zostać ustalone miejsce zamieszkania dziecka, a nadto w jakim zakresie powinny zostać ustalone kontakty rodzica z dzieckiem. W tej kolejności zostaną przeanalizowane problemy pojawiające się w niniejszej sprawie.

\section{DZIECKO W RODZINIE}

Wiadome jest, że dziecko nie potrafi w należyty sposób samodzielnie zabezpieczyć swojego dobra, tym bardziej zaspokoić swoich potrzeb ani bronić swoich praw i interesów. Dlatego też ustawodawca poprzez art. $95 \$ 1$ Kodeksu rodzinnego i opiekuńczego (dalej: k.r.o.) ${ }^{6}$ nałożył na rodziców obowiązek wykonywania pieczy zarówno nad osobą, jak i majątkiem dziecka, ale także

6 Ustawa z dnia 25 lutego 1964 r. - Kodeks rodzinny i opiekuńczy (tekst jedn. Dz.U. z 2020 r. poz. 1359). 
wychowania dziecka z poszanowaniem jego godności i praw. Z kolei w treści art. $96 \$ 1$ k.r.o. wskazano expressis verbis, że wychowanie dziecka polega na trosce o jego fizyczny i duchowny rozwój, a kierowane powinno być tak, aby należycie przygotować dziecko do pracy dla dobra społeczeństwa odpowiednio do jego uzdolnień. Oznacza to tyle, że rodzice powinni wpajać dziecku zasady moralności oraz współżycia społecznego, wzbudzać pracowitość, sumienność oraz poczucie obowiązku, a także wykształcić nawyk respektowania cudzej własności. Obecnie jednak można odnieść wrażenie, iż nowoczesne rozumienie rodzicielstwa wyklucza proponowanie przez rodziców rozmów, doświadczeń czy zainteresowanie szerszą problematyką związaną z budowaniem sfery etycznej, moralnej czy religijnej u dziecka. Co więcej, w środkach masowego przekazu rodzice chwalą się osiągnięciami intelektualnymi, natomiast sfera duchowa $w$ rozmowach pomiędzy rodzicami nie istnieje ${ }^{7}$. Problem pojawia się również w sytuacji, gdy dochodzi do rozpadu rodziny za sprawą rozwodu czy rozstania. Niewłaściwe relacje między rodzicami rodzą konflikty i napięcia, a tym samym brak porozumienia w kwestiach związanych $\mathrm{z}$ wychowaniem dziecka. Zwykle w momencie rozpadu małżeństwa czy też konkubinatu konflikt między rodzicami powoduje u dziecka wystąpienie zaburzeń emocjonalnych. Z kolei rodzice swoje wkładają mnóstwo zaangażowania, aby dowieść zarówno sobie, jak i partnerowi czy dzieciom lub otoczeniu, że proces wychowania dziecka jest dla nich najważniejszy. W związku z tym niejednokrotnie swojemu partnerowi zarzucają przemoc psychiczną i/lub fizyczną, alkoholizm, brak dbałości o rodzinę czy chorobę psychiczną. Tym sposobem dziecko staje się punktem centralnym w kręgu relacji rodzinnych, a jednocześnie osią konfliktu . W ostateczności w wyniku braku jakiegokolwiek porozumienia rodzice występują na drogę sądową w celu uregulowania sytuacji dziecka, bowiem rodzic dziecka, który z winy byłego partnera nie może kontaktować się z małoletnim, może skutecznie żądać ochrony naruszonych dóbr osobistych. Niemożność spotykania się z dzieckiem wiąże się z cierpieniem emocjonalnym9.

7 P. Sitek, Aspekty prawne struktury rodziny a ambiwalentność koncepcji partnerstwa w stosunkach rodzicielskich z dziećmi, „Journal of Modern Science” 2014, nr 1/20.

8 A. Czerederecka, Rozwód a rywalizacja o opiekę nad dziećmi, WKP 2020, http://sip.lex.pl/ (dostęp: 15.06.2021).

9 P. Aleksandra, Brak kontaktu z dzieckiem narusza więzi rodzinne rodzica, http://sip.lex.pl/ (dostęp: 15.06.2021). 


\section{ROZPOZNANIE WNIOSKU O ZABEZPIECZENIE}

W związku z przytoczonym powyżej stanem faktycznym należy w pierwszej kolejności ustalić, który sąd jest właściwy dla rozpoznania wniosku. Warto zaznaczyć, iż rodzice w Rodzicielskim Planie Wychowawczym ustalili opiekę naprzemienną. Z kolei z uwagi na brak wcześniejszych formalnych ustaleń dotyczących miejsca zamieszkania dziecka a zarazem w zgodzie z ustalonym Rodzicielskim Planem Wychowawczym sądem właściwym będzie sąd właściwy dla miejsca, w którym miał przebywać małoletni w dniu złożenia wniosku do sądu, tj. w tym przypadku miejsca zamieszkania ojca. Bowiem zgodnie $\mathrm{z}$ art. $569 \$ 1$ k.p.c. „właściwy wyłącznie jest sąd opiekuńczy miejsca zamieszkania osoby, której postępowanie ma dotyczyć, a w braku miejsca zamieszkania - sąd opiekuńczy miejsca jej pobytu”.

Kolejną kwestią jest rozpoznanie wniosku o zabezpieczenie zgodnie z dyspozycją art. 7561 k.p.c. po przeprowadzeniu rozprawy. Celem tego unormowania jest wyjaśnienie przez sąd wszelkich wątpliwości, jakie mogą zostać ujawnione podczas regulowania pieczy nad małoletnimi dziećmi oraz kontaktów $\mathrm{z}$ dzieckiem, ale również umożliwienie stronom zajęcia stanowiska ${ }^{10}$.

W zaistniałej sytuacji po przeprowadzeniu pierwszej rozprawy i wysłuchaniu stron sąd wydał postanowienie na posiedzeniu niejawnym jako niecierpiące zwłoki. Należy zaznaczyć, iż postanowienie to zostało wydane niezwłocznie po nadejściu żądanych sprawozdań z wywiadów kuratora, z powodu braku którego nie odbyła się poprzednia rozprawa. Sąd w postanowieniu zabezpieczającym oddał dziecko pod bezpośrednią opiekę ojca, ustalając tym samym miejsce zamieszkania dziecka na czas postępowania w każdorazowym miejscu zamieszkania ojca. Jednocześnie sąd ustalił kontakty dziecka z matką w obecności kuratora wraz z obowiązkiem ojca do wydania dziecka celem realizacji kontaktu. Dodatkowo ze względu na dobro dziecka zobowiązano rodziców do objęcia małoletniego opieką psychologiczną, a w celu kontroli wykonania zobowiązań ustalono nadzór kuratora sądowego.

10 T. Szanciło (red.), Komentarz do art. 7561 kodeksu postepowania cywilnego, t. 2, wyd. 1, C.H. Beck, Warszawa 2019. 
Słusznie wskazuje Patryk Aleksandra, że:

regulacja art. 109 k.r.o. ma na celu zabezpieczenie interesów osób małoletnich, których dobro jest zagrożone w przypadku działania lub zaniechania jego rodziców, które w rezultacie wyrządza szkodę dziecku. Przyjmuje się, że do ingerencji sądu opiekuńczego nie jest konieczne rzeczywiste naruszenie dobra dziecka - wystarczająca przesłanką podjęcia działań jest sam stan zagrożenia, uzasadniajacy konieczność dogłębnej analizy sytuacji opiekuńczo-wychowawczej małoletniego. W wielu przypadkach dochodzi przecież do naruszenia interesów osób małoletnich, warunkujących konieczność zmodyfikowania zakresu władzy rodzicielskiej - w trosce o dobro dziecka. W takich przypadkach uaktywnia się rola sądu opiekuńczego. Nie ulega wątpliwości, że wnikanie sadu opiekuńczego w sprawy rodziny nie jest przejawem represjonowania jej za zaniedbania $w$ stosunku do dziecka, ale ma na celu eliminacje dalszych naruszeń i poprawę sytuacji rodzinnej ${ }^{11}$.

Sąd, wydając takie orzeczenie, uznał, iż ojciec uprawdopodobnił w sposób dostateczny istnienie interesu prawnego w udzieleniu zabezpieczenia. Zważył, iż za niewłaściwe należy uznać postępowanie obojga rodziców, którzy nie wydają sobie dziecka na kontakty i nie stosują się do wcześniejszych ustaleń. Zebrany dotychczas materiał dowodowy zdaniem sądu nie wykazał, aby ojciec niewłaściwie zajmował się synem. A na jego korzyść przemawiała karalność matki za prowadzenie samochodu pod wpływem alkoholu. Nie bez znaczenia pozostał fakt, że matka wykorzystywała dziecko do celów reklamowych ze względu na swoją aktywność w mediach społecznościowych, a tym samym upubliczniała w nich wizerunek dziecka. Jak wiadomo, świat, który jest kreowany w mediach, z jednej strony jest pełen sukcesów, osiągnięć, nowych szans rozwojowych, zaś z drugiej jest to świat chaosu, przemocy, wojen, dyskryminacji i okrucieństwa, które przenikną do życia dziecka ${ }^{12}$. W omawianym przypadku matka wykazuje objawy uzależnienia od Internetu i mediów społecznościowych, wciągając tym samym w wirtualny świat swojego syna. W ocenie sądu matka nie sprawowała właściwie opieki nad synem, a nadto ma problemy psychiczne związane z niestabilnym nastrojem, depresją i zaburzeniami odżywiania, a co więcej,

11 P. Aleksandra, Kontakty z małoletnim a ograniczenie władzy rodzicielskiej, glosa do uchwały SN z dnia 28 listopada 2012 r., III CZP 74/12, http://sip.lex.pl/ (dostęp: 15.06.2021).

12 P. Pawlak, Źródła zagrożenia w prawidłowym wychowaniu dzieci i młodzieży, UKSW w Warszawie, online (dostęp: 11.06.2021). 
siłą odebrała dziecko od ojca. Dodatkowym argumentem był fakt, iż chłopiec był zapisany do przedszkola w miejscu zamieszkania ojca, co uzasadniało jego zamieszkanie u ojca. Jednak zasadne było ustalenie zasad kontaktów dziecka z matką, gdyż w ocenie sądu brak regulacji w tym zakresie będzie prowadził do dalszej eskalacji konfliktu i ostatecznie utrudni wykonanie zapadłego orzeczenia kończącego postępowanie. Stan faktyczny sąd ustalił na podstawie wyjaśnień stron w zakresie wniosku dotyczącego zabezpieczenia, jak również na podstawie dokumentów odnoszących się do kwestii związanych z zabezpieczeniem zawartych w aktach sprawy. Sąd miał także na względzie rozbieżność między dobrem dziecka rozumianym przez każdego z rodziców i rozumianym w sposób obiektywny.

\section{ZAŻALENIE NA POSTANOWIENIE ZABEZPIECZAJĄCE}

Zgodnie $z$ art. $741 \S 1$ i 2 k.p.c. na postanowienie sądu pierwszej instancji przysługuje tzw. zażalenie poziome, tzn. zażalenie do tego samego sądu. Warto wspomnieć, iż wniesienie zażalenia nie wstrzymuje wykonania zapadłego w sprawie postanowienia zabezpieczającego, chyba że nastąpi to zgodnie z dyspozycją art. 396 k.p.c. na zasadach ogólnych.

Matka skorzystała z przysługującego jej prawa i wniosła zażalenie na postanowienie zabezpieczające, zarzucając naruszenie przepisów postępowania, które mogło mieć wpływ na treść wydanego orzeczenia, tj.:

rażące naruszenie art. 7561 k.p.c. poprzez przyjęcie w niniejszej sprawie, że zachodzi wypadek niecierpiący zwłoki, podczas gdy sąd nie uzasadnił, co było przyczyną wydania postanowienia na posiedzeniu niejawnym;

naruszenie art. 3271 k.p.c. w zw. z art. 361 k.p.c., polegające na sporządzeniu lakonicznego uzasadnienia, z którego nie wynika, które dowody i w jakim zakresie sąd uznał za wiarygodne oraz na których dowodach się oparł;

naruszenie art. $233 \$ 1$ k.p.c. $w$ zw. $z$ art. $13 \$ 2$ k.p.c., ponieważ sąd błędnie przyjął, iż ojciec nie utrudniał kontaktów dziecka z matką, mimo iż sąd dysponuje obszerną dokumentacją w tym zakresie, oraz że przyjął za wiarygodne twierdzenia ojca dotyczące stosowania przemocy przez matkę wobec syna. Zarzucono również, że sąd przyjął, iż dotychczasowy materiał dowodowy nie 
dostarczył podstaw do twierdzenia, że ojciec w sposób niewłaściwy zajmuje się dzieckiem.

Podstawą zażalenia było również naruszenie prawa materialnego, tj. rażące naruszenie art. $113 \$ 1$ k.r.o. w zw. z art. $1131 \$ 1$ k.r.o. w zw. z art. $1132 \$ 2$ pkt 3 k.r.o. poprzez jego błędną wykładnię i w konsekwencji orzeczenie kontaktów matki z małoletnim synem w bardzo wąskim zakresie, a ponadto w obecności kuratora. Matka tym samym wniosła o zmianę zaskarżonego postanowienia przez sąd rozpoznający zażalenie lub o uchylenie zaskarżonego postanowienia i przekazanie do ponownego rozpoznania przez sąd I instancji.

Zgodnie $\mathrm{z}$ art. $741 \$ 2$ k.p.c. zaskarżone postanowienie rozpoznano na posiedzeniu niejawnym w składzie trzech sędziów sądu rejonowego. Wydanym postanowieniem zmieniono postanowienie zabezpieczające w zakresie oddania małoletniego pod opiekę ojca, ustalenia zasad kontaktów matki z dzieckiem oraz zobowiązania ojca do wydania dziecka matce i tym samym oddalono wnioski o udzielenie zabezpieczenia w tym zakresie.

Sąd rozpoznający zażalenie w uzasadnieniu wskazał, iż zaskarżone postanowienie w przedmiocie zabezpieczenia zostało wydane na posiedzeniu niejawnym w zgodzie z obowiązującymi przepisami oraz wobec uzasadnionych okoliczności zaistniałych w sprawie. Zauważyć należy, iż od początku trwania postępowania matka, zarówno w składanych wnioskach, jak i formułowanych pismach, wielokrotnie podkreślała, że sprawa ma pilny charakter. Podczas posiedzenia niejawnego oceniono prawidłowość przeprowadzonego postępowania, ale także trafność subsumpcji stanu faktycznego do zastosowanych przepisów prawa oraz prawidłowość przedstawionych rozważań. Sąd rozpoznający zażalenie nie dopatrzył się naruszenia przepisów postępowania, a tym samym art. 233 k.p.c., wskazując, iż ustalenia stanu faktycznego oraz rozważania sądu I instancji były prawidłowe. Wskazać należy, że sąd rozpoznający zażalenie w momencie orzekania dysponował obszerniejszym materiałem dowodowym, jaki został zgromadzony w sprawie. Tym samym sąd ten był zobligowany do poczynienia własnych ustaleń faktycznych, które stanowiły podstawę rozstrzygnięcia oraz dokonania oceny zebranego materiału procesowego. Materiał procesowy zaś nie jest równoznaczny z materiałem dowodowym, gdyż obejmuje także wszelkie oświadczenia, czynności stron oraz zdarzenia i stany, które umożliwiają podjęcie ustaleń faktycznych w sposób bezdowodowy, tj. za pomocą domniemań 
faktycznych, jak i prawnych, przyznania okoliczności faktycznych czy też okoliczności powszechnie znanych ${ }^{13}$. Zdaniem sądu bezsporny jest fakt, że między rodzicami małoletniego istnieje konflikt i dlatego są w stanie porozumieć się w kwestiach związanych z wychowaniem syna, jak i opieki nad nim. Każde z rodziców popełnia błędy wychowawcze, przed którymi żadna ze stron nie uchroniła także dziecka. Co więcej, każde z rodziców twierdzi, że jest rodzicem pierwszoplanowym i działa zgodnie z dobrem dziecka. Tymczasem ani matka, ani ojciec nie podejmują żadnych czynności, które zmierzałyby w jakikolwiek sposób do ochrony dziecka przed konfliktem rodziców. Nie sposób pominąć zupełnie sprzecznych opinii psychologicznych złożonych przez każdego z rodziców, które mają charakter prywatny. Niemniej jednak nie można pominąć wyjaśnienia zawartych w ich rozbieżności w zakresie predyspozycji wychowawczych obojga rodziców. W niniejszej sprawie strony obopólnie obarczają się odpowiedzialnością za zaistniałą sytuację, jednak w ocenie sądu brak jest obiektywnych dowodów mogących świadczyć o prawdziwości twierdzeń którejkolwiek ze stron w zakresie predyspozycji wychowawczych i możliwości sprawowania stałej pieczy nad małoletnim. Tym samym sąd rozpoznający zażalenie wziął pod uwagę, że na tym etapie postępowania ustalenie w trybie zabezpieczenia miejsca zamieszkania dziecka byłoby nieuzasadnione, ponieważ przedstawione stanowiska rodziców wymagają zweryfikowania w toku dalszego postepowania powodowego, a nadto konieczne jest ustalenie, które $\mathrm{z}$ rodziców może w większym stopniu zapewnić prawidłowe sprawowanie pieczy rodzicielskiej.

\section{OPINIA BIEGEYCH OPINIODAWCZEGO ZESPOEU SĄDOWYCH SPECJALISTÓW}

W toku postępowania, po wydaniu zaskarżonego postanowienia zabezpieczającego, zostały przeprowadzone badania biegłych na okoliczność ustalenia relacji między małoletnim a każdym z rodziców oraz predyspozycji każdego z rodziców do sprawowania bezpośredniej opieki nad dzieckiem. Opinia

13 M. Manowska (red.), Kodeks postępowania cywilnego. Komentarz, komentarz do art. 382 kodeksu postępowania cywilnego, t. 1, art. 1-47716, wyd. 4, Wydawnictwo Wolters Kluwer, Warszawa 2021. 
biegłych upewniła sąd, iż małoletni związany jest z każdym z rodziców, jednak oboje rodzice wymagają wsparcia w zakresie wychowania dziecka i wywiązywania się z obowiązku współpracy z drugim rodzicem i dbania o więzi dziecka z nim. Matka dodatkowo miała zaleconą konsultację u terapeuty uzależnień i podjęcie odpowiedniej terapii. Jednocześnie zalecono, aby jej kontakty z dzieckiem były monitorowane do momentu ukończenia wskazanej terapii.

Wobec powyższego ojciec ponownie złożył wniosek o wydanie postanowienia w trybie zabezpieczenia, w którym wnosił o ustalenie miejsca zamieszkania dziecka w każdorazowym miejscu zamieszkania ojca, uregulowanie kontaktów matki z dzieckiem przeprowadzanych w obecności kuratora sądowego, nakazanie wydania dziecka ojcu oraz zobowiązanie matki dziecka do podjęcia terapii psychologicznej i terapii uzależnień.

\section{ROZPOZNANIE WNIOSKU O ZABEZPIECZENIE}

Z uwagi na narastający konflikt między rodzicami po przeprowadzeniu kolejnych rozpraw i przesłuchaniu świadków sąd na rozprawie wydał postanowienie w przedmiocie zabezpieczenia, w którym zobowiązał rodziców do podjęcia wspólnej terapii mającej na celu rozwiązanie konfliktu między nimi i wypracowanie współpracy co do sposobu wykonywania władzy rodzicielskiej. Zobowiązano ich także do przekazania sobie wzajemnie wszelkich numerów telefonów oraz danych komunikatorów internetowych, za pomocą których będą się komunikować, a nadto zobowiązano matkę do zapewnienia ojcu regularnego kontaktu z synem, również za pomocą środków porozumiewania się na odległość, minimum trzy razy w tygodniu. Matka została zobowiązana przez sąd do wskazania adresu pobytu dziecka i informowania o każdej zmianie tego adresu oraz do stawiania się wraz z synem raz w tygodniu na dyżurze kuratora sądowego. Jednocześnie nad wykonaniem zobowiązań ustanowiono nadzór kuratora sądowego. 


\section{Podsumowanie}

Od czasu wydania postanowienia zabezpieczającego kontakty ojca z synem odbywają się na postawie ugody zawartej między rodzicami. Zgodnie z tym postanowieniem spotkania te mają miejsce w obecności kuratora sądowego, który składa sprawozdania z przebiegu spotkania. Jak wskazuje kurator, przebiegają one bez zakłóceń i awantur, a dziecko jest szczęśliwe w obecności obojga rodziców. Można więc z całą pewnością stwierdzić, iż w przytoczonym przypadku cel postępowania zabezpieczającego został osiągnięty. Co prawda żadne z rodziców nie było w pełni usatysfakcjonowane $\mathrm{z}$ takiego rozstrzygnięcia, jednak w tym przypadku nie chodzi o satysfakcję rodziców, a o dobro dziecka, które wymaga szczególnej ochrony. Jednocześnie należy zaznaczyć, że rodzice również mają takie samo prawo do kontaktów z dzieckiem, co zostało uregulowane w sposób autonomiczny w przepisach art. 113 i n. k.r.o. Dlatego też na gruncie tych regulacji oboje rodzice domagali się ustalenia kontaktów z dzieckiem oraz określenia jego ram czasowych, częstotliwości i terminów osobistych spotkań lub innych form podtrzymywania więzi ${ }^{14}, \mathrm{tj}$. utrzymania kontaktów, m.in. z wykorzystaniem środków porozumiewania się na odległość. W tym zakresie rodzice mogą korzystać z wszelkich dostępnych możliwości technologicznych. Należy wskazać, że komunikatory dają szansę na szybki i bezpośredni kontakt ${ }^{15}$, a tym samym stają się narzędziem do wywiązania się z nałożonego przez sąd zobowiązania.

Istotne jest, że dzięki postanowieniu zabezpieczającemu dziecko wreszcie uzyskało uregulowane kontakty z obojgiem rodziców i zapewnienie bezpieczeństwa. Jednocześnie postanowienie wpłynęło na zachowania rodziców oraz podjęcie przez nich działań, których zapewne bez zobowiązania sądu by nie podjęli. Zakończyły się również incydenty związane z porwaniami rodzicielskimi, a matka ograniczyła swój udział w mediach społecznościowych. Zaznaczyć należy również, że matka wykorzystała możliwości technologiczne właśnie do zapewnienia kontaktów ojca z dzieckiem.

Odnosząc się do celów niniejszej analizy, należy zauważyć, że sfera kontaktów ma służyć przede wszystkim dobru dziecka, natomiast sąd opiekuńczy,

14 P. Aleksandra, Kontakty $z$ dzieckiem a dobra osobiste, glosa do wyroku sądu apelacyjnego z dnia 29 stycznia 2013 r., I ACa 906/12, http://sip.lex.pl/ (dostęp: 15.06.2021).

15 J. Dziak, Nie tylko pogawędki, czyli rzecz o komunikatorach, „Biuletyn EBIB” 2007, nr 4(85). 
rozpoznając w postępowaniu wniosek o zabezpieczenie kontaktów któregokolwiek rodzica z dzieckiem, musi ustalić przede wszystkim, jaki wpływ na małoletniego będzie miało ustalenie określonych spotkań, w jakim wymiarze czasowym oraz w jakim miejscu powinny te spotkania się odbywać, aby dziecko czuło się dobrze i bezpiecznie ${ }^{16}$. Reasumując, należy wskazać, iż postępowanie zabezpieczające w sprawach opiekuńczych zmierza do uregulowania spraw między rodzicami w zakresie opieki nad dziećmi oraz że niekiedy jest ono niezbędne do prawidłowego toku dalszego postępowania rozpoznawczego.

16 P. Aleksandra, Kontakty $z$ dzieckiem..., dz. cyt. 


\section{BibLIOGRAFIA}

Dziak J., Nie tylko pogawędki, czyli rzecz o komunikatorach, „Biuletyn EBIB” 2007, nr $4(85)$.

Ereciński T. (red.), System prawa procesowego cywilnego. Postępowanie zabezpieczające, Wydawnictwo Wolters Kluwer, Warszawa 2016, s. 27.

Manowska M. (red.), Kodeks postępowania cywilnego. Komentarz, komentarz do art. 382 kodeksu postępowania cywilnego, t. 1, art. 1-47716, wyd. 4, Wydawnictwo Wolters Kluwer, Warszawa 2021.

Osajda K. (red.), Tom V. Kodeks rodzinny i opiekuńczy. Komentarz. Przepisy wprowadzajace KRO, C.H. Beck, Warszawa 2017.

Pietrzykowski K., Kodeks rodzinny i opiekuńczy. Komentarz. Komentarze Kodeksowe, wyd. 6, C.H. Beck, Warszawa 2020.

Rzewuska M., Alimentacja byłego małżonka w ujęciu prawnoporównawczym, [w:] Meandry prawa - teoria i praktyka. Ksiega jubileuszowa prof. zw. dra hab. Mieczysława Goettela, Wyższa Szkoła Policji w Szczytnie, Szczytno 2017.

Sitek P., Aspekty prawne struktury rodziny a ambiwalentność koncepcji partnerstwa $w$ stosunkach rodzicielskich $z$ dziećmi, „Journal of Modern Science” 2014, nr 1/20.

Strzelecka M., Postępowanie w sprawach rozwodowych, „Monitor Prawniczy” 2019, nr 24, s. 1352.

Szanciło T. (red.), Komentarz do art. 7561 kodeksu postepowania cywilnego, t. 2, wyd. 1, C.H. Beck, Warszawa 2019.

\section{ŹRÓDŁA PRAWA}

Ustawa z dnia 17 listopada 1964 r. - Kodeks postępowania cywilnego (tekst jedn. Dz.U. z 2020 r. poz. 1575).

Ustawa z dnia 25 lutego 1964 r. - Kodeks rodzinny i opiekuńczy (tekst jedn. Dz.U. z 2020 r. poz. 1359).

\section{ŹRÓDŁA INTERNETOWE}

Aleksandra P., Brak kontaktu $z$ dzieckiem narusza więzi rodzinne rodzica, http://sip. lex.pl/ (dostęp: 15.06.2021).

Aleksandra P, Kontakty z dzieckiem a dobra osobiste, glosa do wyroku SA z dnia 29 stycznia 2013 r., I ACa 906/12, http://sip.lex.pl/ (dostęp: 15.06.2021).

3. Aleksandra P., Kontakty z małoletnim a ograniczenie władzy rodzicielskiej, glosa do uchwaty SN z dnia 28 listopada 2012 r., III CZP 74/12, http://sip.lex.pl/ (dostęp: 15.06.2021.

4. Czerederecka A., Rozwód a rywalizacja o opiekę nad dziećmi, WKP 2020, http://sip. lex.pl/ (dostęp: 15.06.2021). 
5. Jędrejek G. (red.), Postępowanie cywilne po nowelizacji. Vademecum, WKP 2020, http://sip.lex.pl/ (dostęp: 24.05.2021).

6. Pawlak P., Źródła zagrożenia w prawidłowym wychowaniu dzieci i młodzieży, UKSW $w$ Warszawie, online (dostęp: 11.06.2021).

7. Stępień M., Atrybuty władzy rodzicielskiej, https://repozytorium.uni.wroc.pl/ (dostęp: 14.06.2021). 